Article

\title{
Innovative Strategies for the Use of Reflective Foils for Fruit Colouration to Reduce Plastic Use in Orchards
}

\author{
Patrick Hess ${ }^{1}$, Achim Kunz ${ }^{2}$ and Michael M. Blanke ${ }^{1, *(\mathbb{D}}$ \\ 1 INRES-Horticultural Science, University of Bonn, 53115 Bonn, Germany; Pat_hess@web.de \\ 2 Campus Klein-Altendorf, University of Bonn, 53359 Rheinbach, Germany; akunz@uni-bonn.de \\ * Correspondence: mmblanke@uni-bonn.de
}

check for

updates

Citation: Hess, P.; Kunz, A.; Blanke, M.M. Innovative Strategies for the Use of Reflective Foils for Fruit Colouration to Reduce Plastic Use in Orchards. Sustainability 2021, 13, 73. https:// dx.doi.org/10.3390/su13010073

Received: 11 November 2020 Accepted: 14 December 2020 Published: 23 December 2020

Publisher's Note: MDPI stays neutral with regard to jurisdictional claims in published maps and institutional affiliations.

Copyright: () 2020 by the authors. Licensee MDPI, Basel, Switzerland. This article is an open access article distributed under the terms and conditions of the Creative Commons Attribution (CC BY) license (https: / / creativecommons.org/ licenses/by/4.0/).

\begin{abstract}
Background: Plastic in fruit orchards represents an environmental issue due to large $\mathrm{CO}_{2 \mathrm{eq}}$ emissions associated with its production from fossil fuel and disposal (often incineration). (2) Materials and methods: Apple cv. "Braeburn Hillwell" trees on M9 rootstocks under a hail net were used at Campus Klein-Altendorf (CKA), Germany $\left(50^{\circ} \mathrm{N}\right)$ in 2018 . In order to reduce the use of plastics to improve the red colouration of fruit particularly under hail nets, three alternatives to the current use of reflective mulch in each alleyway between the tree rows were explored, with uncovered grass alleyways as control. About 2800 colour measurements were done in the four weeks prior to harvest on 720 attached fruit below and above $1 \mathrm{~m}$ height in the field, and ca. 6900 additional colour measurements were conducted at harvest. (3) Results: The underlying regulatory mechanisms contrasted between the diffusive reflection of the white woven ground cover (such as Lumilys ${ }^{\mathrm{TM}}$ or Extenday ${ }^{\mathrm{TM}}$ ) in the alleyways and aluminium foil under the trees with regular (straight) light reflection. Good fruit colouring and a plastic reduction were achieved (a) through spreading the white woven ground cover in every other row, and (b) through substituting the white ground cover with aluminium foil ( $80 \%$ recycled). Both methods can reduce greenhouse gas (GHG) emissions (75-110 kg CO $\mathrm{CO}_{2 \mathrm{e}} \mathrm{q}$ ha for the first option a). (4) Conclusion: Plastic use in fruit orchards can be reduced by multiple use of the material in the same or several years, spreading it in every other row or substituting it by another reflective material, a relevant step towards an environment-friendly sustainable horticulture.
\end{abstract}

Keywords: anthocyanin; Extenday ${ }^{\mathrm{TM}}$; fruit colouration; light reflection; Lumilys ${ }^{\mathrm{TM}}$; plastic recycling; reflective films; resource conservation; sustainable horticulture

\section{Introduction}

Criticism concerning food and fruit production at all stages of the supply chain includes unnecessary waste from the field to wholesale, retail, restaurants and the consumer [1-4]. The excessive use of plastic is criticised due to its fossil-fuel based, non-renewable nature, which can constitute a major source of GHG emissions due to production, pollution, waste and possibly micro plastics as important aspects for a sustainable, environment-friendly horticulture.

As a result of climate change and associated changes in the weather system, such as an increase in hailstorms, protective hail nets have become more widespread [3]; the combination of the resultant lack of light under the hail net [5] and warmer autumn temperatures [6] prevents the (red) colouration in many fruits and in many locations worldwide, from Brazil to Chile, Washington DC to Ontario and Bonn to Bologna [3]. The consumer (and trade), however, demands red-coloured fruit. In the consumer's perception, the red colour is associated with a ripe fruit, sweetness and good taste [3,7].

Hence, the objective of the present study was to investigate possible alternatives or modifications to the use of reflective mulch for colouration of fruit such as apricot, apple, (Anjou) pear, (red) grape berry, peach, persimmon (kaki), etc. In other words, the stimulation of the anthocyanin synthesis [8-10] for sustainable cultivation of these fruit 
crops. Apple was chosen here due to its widespread cultivation in many countries with temperate climate zones throughout the world [4]. With ca. 80 million metric tons annual production (FAOSTAT [11]), it counts as the third largest fruit crop worldwide.

\section{Materials and Methods}

\subsection{Location, Fruit Trees, Colour Measurement and Maturity Indexing}

Nine-year-old cv. 'Braeburn Hillwell' apple trees on M9 rootstocks were cultivated at Campus Klein-Altendorf (CKA), University of Bonn, Germany $\left(50^{\circ} \mathrm{N}\right)$. The trees were trained to slender spindles and planted N-S to optimise light conditions (Jackson and Palmer, 1972) [12]. Fruit colour was measured with a portable i1 Pro (Xrite, Michigan, USA) in the lower third ( $<1 \mathrm{~m}$ tree height) and middle third $(<1 \mathrm{~m})$ of the trees, since fruit in the shaded lower parts of the tree canopy (Figures 1 and 2) are particularly prone to poor colouration. In these lower and middle parts of the tree, five fruits were marked in the west and five in the east tree periphery. Colour was repeatedly measured four times per fruit, i.e., every $90^{\circ}$ around the fruit equator, on these still attached fruits and marked spots, resulting in 2800 values, and averaged for Figure 3, while colour values measured on the down-facing side of the fruit under $1 \mathrm{~m}$ height are presented in Figure 4 . The second round of colour measurements was on harvested fruit using automated machine grading in an MSE 2000 (Greefa, Geldermalsen, Holland) with dedicated single fruit evaluation [13]. The 100 fruit samples for maturity indexing at two dates comprised ten apples per plot and treatment, i.e., five fruits from the east side and five fruits from the west side of the tree, and included the assessment of starch degradation, sugar content and fruit firmness, using standard methods [5].

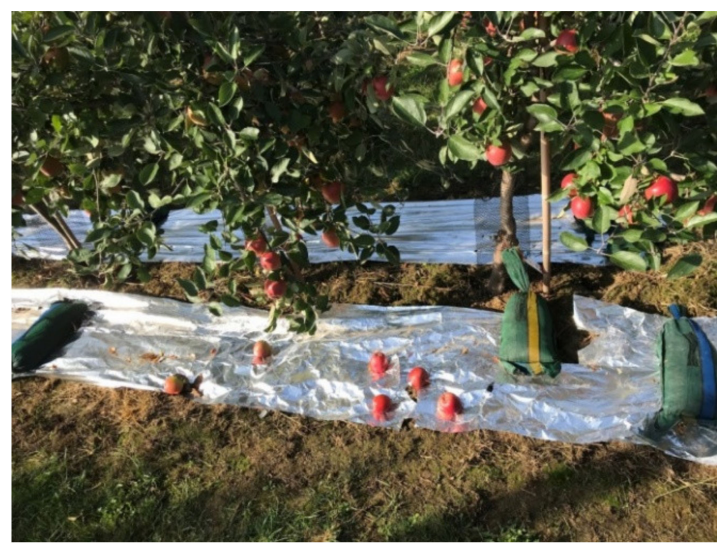

(a)

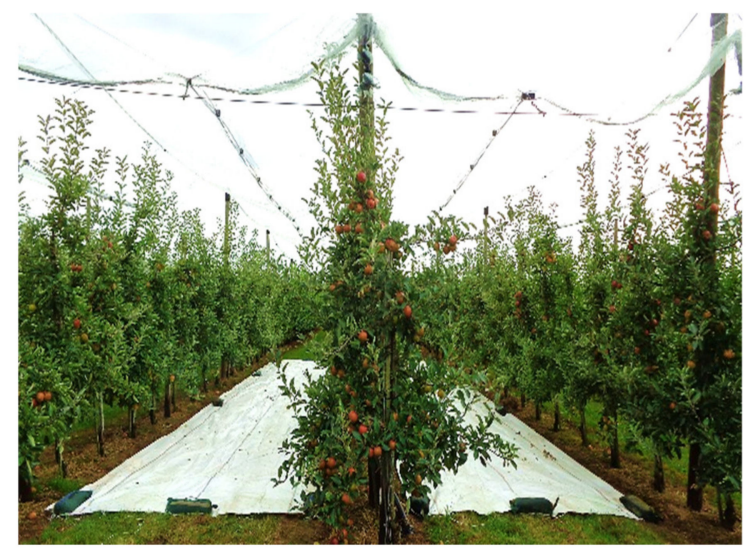

(b)

Figure 1. Different approaches using (a) (recycled) aluminium foil directly under the trees (left), or (b) Lumilys woven textile both after 6 weeks exposure, both at the end of the experiment before harvest.

\begin{tabular}{|c|c|c|c|c|c|c|c|}
\hline \multicolumn{2}{|c|}{ Initial position } & \multicolumn{2}{|c|}{$1^{\text {st }}$ relocation } & \multicolumn{2}{|c|}{$2^{\text {nd }}$ relocation } & \multicolumn{2}{|c|}{$3^{\text {rd }}$ relocation } \\
\hline \multicolumn{2}{|c|}{30.08 .18} & \multicolumn{2}{|c|}{12.09 .18} & \multicolumn{2}{|c|}{25.09 .18} & \multicolumn{2}{|c|}{04.10 .18} \\
\hline Plot 1 & Plot 2 & Plot 1 & Plot 2 & Plot 1 & Plot2 & Plot1 & Plot2 \\
\hline Lumilys & Grass & Grass & Lumilys & Lumilys & Grass & Grass & Lumilys \\
\hline Grass & Lumilys & Lumilys & Grass & Grass & Lumilys & Lumilys & Grass \\
\hline
\end{tabular}

Figure 2. Pictorial representation of moving Lumilys mulch within the same row ("relocation") in autumn 2018. 


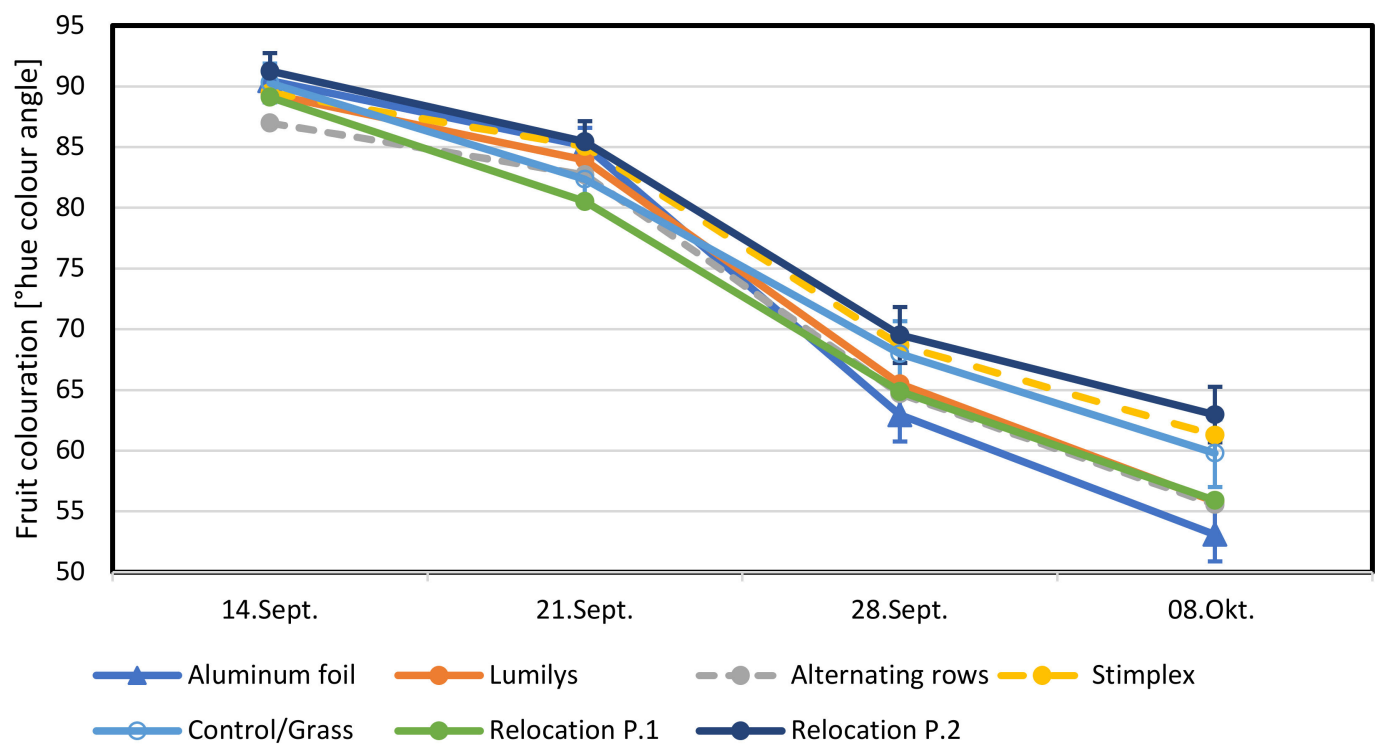

Figure 3. Effect of plastic (closed circles) and aluminium (triangles) reflective mulches or chemical measures (Biostimulant Stimplex ${ }^{\mathrm{TM}}$ ) relative to the control (open circles) on red colour formation (anthocyanin synthesis) at the fruit equator as a decline in 'hue colour angles for apple cv. 'Braeburn Hillwell' at Campus Klein-Altendorf in 2018 (n = 100 colour measurements per treatment and date plus SEs at the $5 \%$ error level).

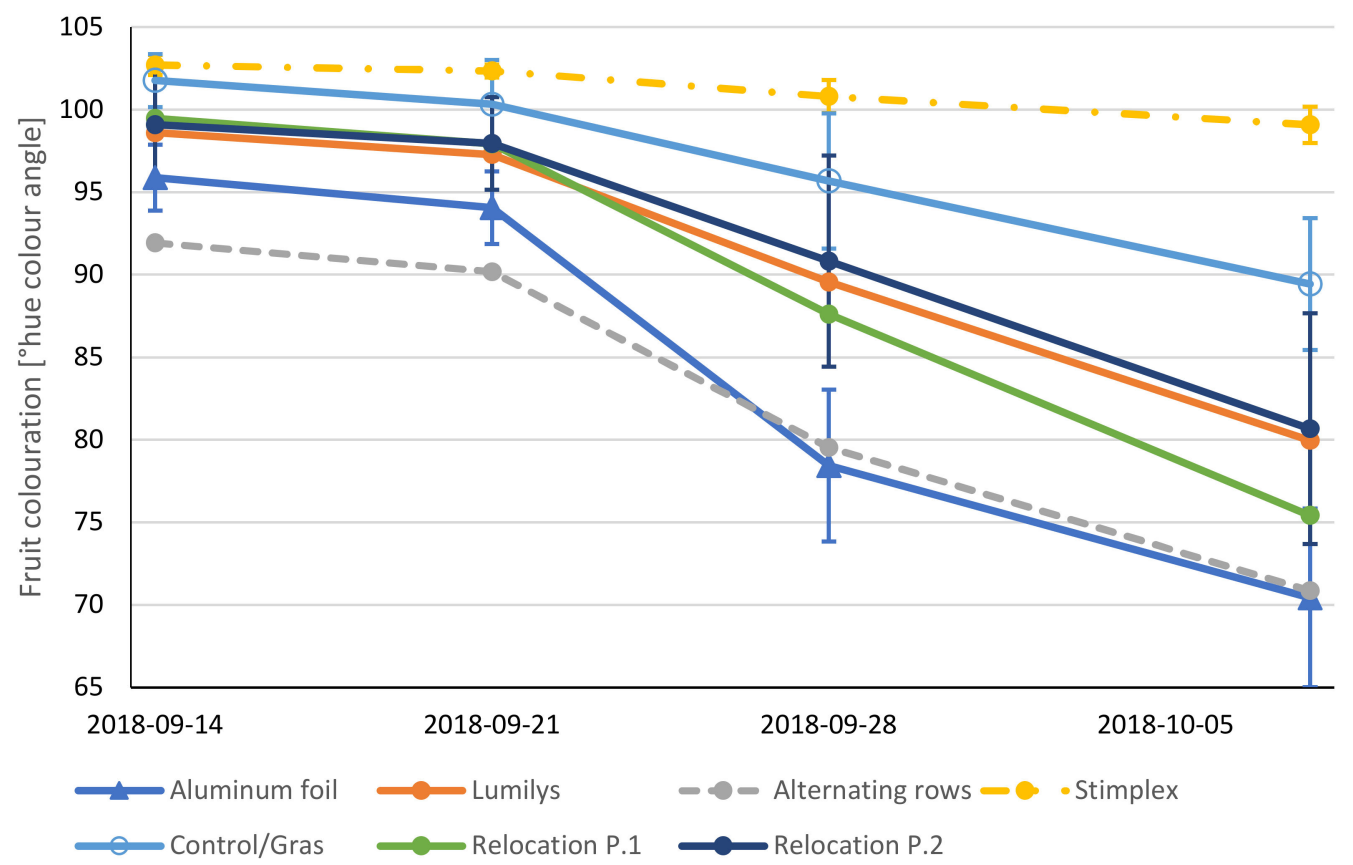

Figure 4. Hue colour angle of the bottom side of apples below $1 \mathbf{m}$ height exposed to aluminium foil (triangle), Lumilys ${ }^{R}$ reflective (plastic) mulch, Lumilys ${ }^{R}$ in alternating tree rows (closed circles), the biostimulant Stimplex ${ }^{R}$, control/grass (open circle) and relocation P.1 and P.2 for the four measurement dates ( $\mathrm{n}=10$ / per treatment and measurement day plus SEs at the 5\% error level for Stimplex ${ }^{\mathrm{TM}}$ control, relocation P2 and P1 and aluminium foil).

\subsection{Reflective Mulches and Biostimulants}

Reflective white woven textile mulch type Lumilys ${ }^{\mathrm{TM}}\left(100 \mathrm{~g} / \mathrm{m}^{2}\right.$; Beaulieu Textiles, Belgium) [14] was spread on 30 August 2018, i.e., ca. five weeks prior to the anticipated harvest (traditional way of using reflectors), with grassed alleyways without ground cover as control. The $2.6 \mathrm{~m}$ wide white polypropylene mulch cloth leaves a ca. $50 \mathrm{~cm}$ wide gap for soil respiration/aeration and water uptake close to the tree trunk. 
The innovative alternatives to the white reflective groundcover in every row included (a) spreading only every other row (thereby saving 50\% of the plastic) (Figure 2) and (b) the substitution of the (diffuse) reflective mulch by aluminium foil (type Profissimo $\AA_{\text {, }}$ dm pharmacies, Karlsruhe, Germany) (regular reflection) under the trees, leaving a $2.3 \mathrm{~m}$ wide gap on the grassed alleyway 1 ; the foil used was made from $80 \%$ recycled aluminium. The biostimulant Stimplex $\AA /$ Acadian $\AA$, based on extracts of the brown algae (Ascophyllum nodorum; Acadian Seaplants Co., Dartmouth, NS, Canada), was our third alternative (Table 1).

Table 1. Experimental design to stimulate fruit colour at Klein-Altendorf in 2018.

\begin{tabular}{ccc}
\hline Treatment & $\begin{array}{c}\text { Spreading Time or } \\
\text { Treatment Date }\end{array}$ & Dosage/Relocation \\
\hline \multicolumn{3}{c}{ Aluminium } \\
\hline Aluminium foil & 30 August 2018 & n.a. \\
\hline $\begin{array}{c}\text { Lumilys every row (current } \\
\text { standard) }\end{array}$ & 30 August 2018 & n.a. \\
\hline $\begin{array}{c}\text { Lumilys in alternating rows } \\
\text { Lumilys relocation 1 }\end{array}$ & 30 August 2018 & n.a. \\
\hline Lumilys relocation 2 & 30 August 2018 & 12 Sept.; 25 Sept.; 4 Oct. 2018 \\
\hline \multicolumn{1}{c}{ 30 August 2018 } & 12 Sept.; 25 Sept.; 4 Oct. 2018 \\
\hline $\begin{array}{c}\text { Control 1 with uncovered } \\
\text { grass }\end{array}$ & n.a. & n.a. \\
\hline Control 2 with uncovered \\
grass
\end{tabular}

The white woven reflective mulch (Lumilys ${ }^{\mathrm{TM}}$ ) was moved ca. every ten days in the fruit colouration period of six weeks before the harvest. In this relocation trial, the reflective mulch was spread in the alleyway either on the west side or the east side of the apple trees.

\subsection{Statistics}

The experiment comprised 80 apple trees. Each treatment consisted of ten trees plus one border tree, and the plots were replicated. A hundred and forty maturity tests were conducted at two dates on 10 apples per plot and treatment, i.e., five fruits from the east and five fruits from the west side of the tree, and averaged. A total of 2800 colour angle measurements were performed in the orchard on 560 attached fruits below and above 1 $\mathrm{m}$ height (Figure 3). All 5,515 apple fruits in the experiment were subjected to automated grading for colour (Figure 4), ca. 700 apples per treatment. Data were checked for normal distribution and homogeneity of variance, and then subjected to an analysis of variance (ANOVA) using Excel's statistical function and SEs at the 5\% error level presented in Figures 3 and 4 .

\section{Results and Discussion}

Repeated non-destructive colour measurements on the attached fruit (Figure 3) show the decline in the hue colour angle during fruit maturation, i.e., progressive development of red (anthocyanin) colour formation of the apple cv. 'Braeburn Hillwell' fruit. With about $63^{\circ}$ hue, the least red colouration was observed with the relocation of the reflective mulch within the same row and the uncovered grassed as control (60 ${ }^{\circ}$ hue; Figure 3$)$. 


\subsection{Development of Fruit Colouration on the Tree and Effect of Fruit Position in the Canopy on Colouration}

The best fruit colouration ( $55^{\circ} \mathrm{hue}$ ) was observed with reflective mulch every other row/alleyway ("alternating rows"; Figures 2 and 3) and the aluminium foil under the trees $\left(53^{\circ}\right.$ hue; values averaged over the east and west side and over $<1 \mathrm{~m}$ and $>1 \mathrm{~m}$ ).

Both polypropylene mulch relocations in plot 1 and plot 2 (Figure 2) and their use in every other row ("alternating") provide a plastic reduction of $50 \%$. The colour of the apple fruit from relocation plot $1\left(56^{\circ}\right.$ hue) and relocation plot $2\left(62^{\circ}\right.$ hue) differed drastically, particularly in the period during 28 September to 8 October, with an apparent discrepancy between the decrease in the ${ }^{\circ}$ hue colour angle of $9^{\circ}$ hue for apple in plot 1 and the $3{ }^{\circ}$ hue for relocation plot 2 (Figure 3). In plot 1 the relocation of the reflective sheets within the same row had the strongest colouration effect, and the fruit were exposed longer to Lumilys reflective mulch in the alleyway on the east side than in relocation plot 2 . The reflective mulch (Lumilys) appeared more effective on the less sunny east side of the apple tree rows with north-south planting, especially in late autumn with a decreasing solar angle, which has not been shown before, to our knowledge. Fruit on the west side of the trees benefited from sufficient PAR and UVB radiation for colouration (anthocyanin synthesis).

The lower, more shaded and green side of the apple fruit, particularly in the bottom of the tree canopy below $1 \mathrm{~m}$, is severely affected by the lack of light. This bottom side of the fruit below $1 \mathrm{~m}$ in the tree canopy benefited most, in terms of the best red colour, from the aluminium foil directly under the tree $\left(70.4^{\circ} \mathrm{hue}\right)$ and Lumilys ${ }^{R}$ in every other ("alternating") alleyway $\left(70.8^{\circ} \mathrm{hue}\right.$ ) (Figure 4$)$.

When the chemical biostimulant Stimplex ${ }^{\mathrm{TM}}$ was applied, however, the colouration on the lower side of apple fruits was not improved ( $99^{\circ}$ hue), relative to the untreated control (grass; $89.4^{\circ}$ hue; Figure 4), and hence appeared unsuitable for this purpose.

The use of aluminium foil under the tree would mean a $100 \%$ reduction of plastic for fruit colouration in the orchard. Other (organic) alternatives like fresh wheat straw, which conveniently becomes available concomitantly, and bio-degradable white sports field paint failed in previous studies in our location in the Northern hemisphere [8], as well as evaporative cooling [15] and other biostimulants $[15,16]$.

\subsection{Colour Assessment-Automated Grading of Harvested Fruit}

The colour threshold for the machine grading of all ca. 6900 harvested apple fruits was set to $>50 \%$ red peel colouration for the classification as premium fruit. Reflective mulch every in other row ("alternating") had the largest share, with $81 \%$ in this sorting category ( $>50 \%$ surface red), followed by the aluminium foil, with $80 \%$ in relation to the traditional design of the reflective mulch in every row $(75 \%)$. Where Lumilys mulch was relocated three times within the same row to save $50 \%$ of plastic, fruit from relocation plot 1 gained a similar hue value as Lumilys, with $73 \%$, but that from relocation plot 2 exhibited a much lower value, with only $59 \%$, i.e., less red colour (Figure 2). This discrepancy between fruit colour in plot 1 and plot 2 is in line with the results of the field colour measurements with attached fruit (Figure 1a). The control with uncovered grassed alleyways showed only $65 \%$ fruit in this premium colour category, as with the biostimulant Stimplex (Figure 5). The results of the colour sorting (Figure 5) correspond to the results of the colour angle measurements in the field (Figure 3), which also showed the best red fruit colour in both the application of the reflective mulch (Lumilys ${ }^{\mathrm{R}}$ in alternating tree rows and the aluminium foil directly underneath the trees). The results of the colour measurements of attached apple fruits in the field ( $\mathrm{n}=3600$ measurements) and of the automated sorting machine of ca. 6900 fruits show that the aluminium foil directly underneath the trees leads to apples with a better red colouring, thereby substituting $100 \%$ of plastic mulch by (recycled) aluminium. The reflective mulch (Lumilys) in the alleyway of every other row ("alternating") provided an equally good red colour, thereby reducing the plastic mulch input in the orchard by $50 \%$. 


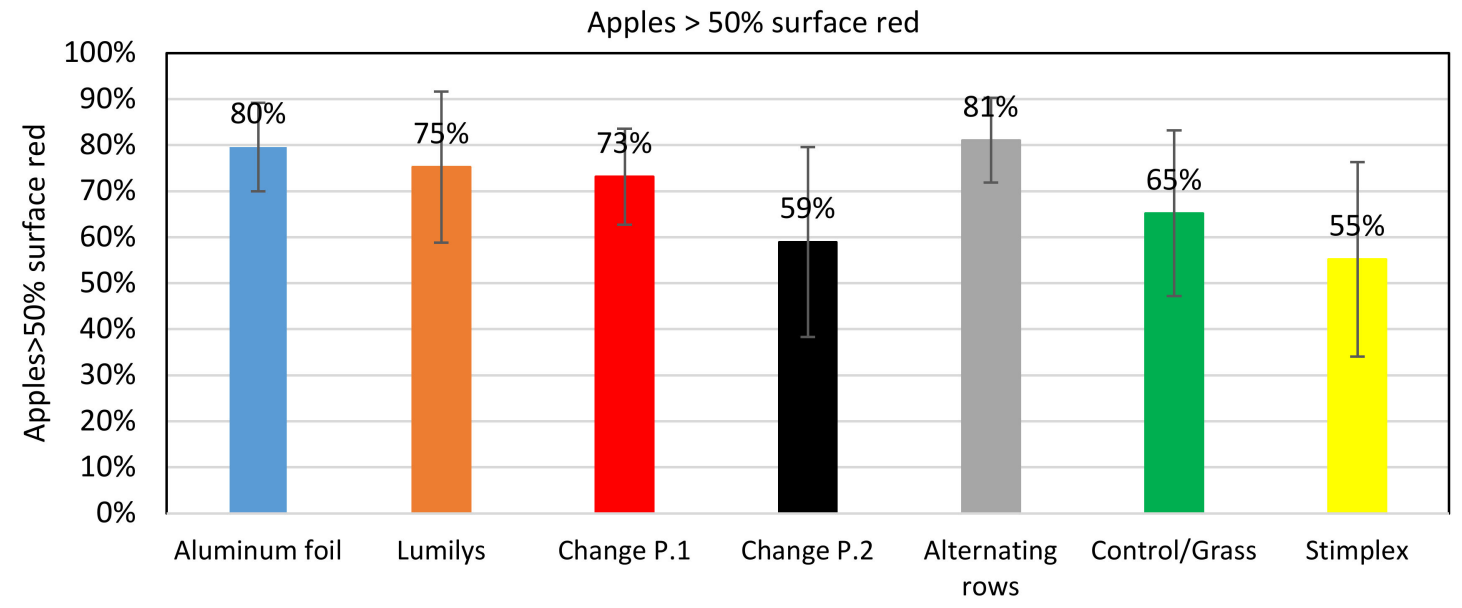

Figure 5. Effect of colour enhancing measures on the portion of apples with more than $50 \%$ red colour on their surface, with SDs at the $5 \%$ error level from machine sorting results $(n=6900)$.

\subsection{Maturity Indexing of Apple Fruit}

The maturity indexing showed that the biostimulant Stimplex ${ }^{\mathrm{TM}}$ accelerated ripening (Table 2) and advanced fruit maturation by one week, causing it to ripen as early as 4 October 2018. The red colour of the apples was bright red, and they retained their firmness (Table 4). An early harvest could lead to an increase in the sales price for apples of an early variety (such as "Gala") at an early location [13] (Table 2). All other treatments with reflective mulches had no influence on fruit maturity and, above all, maintained firmness as a pre-requisite for storability.

Table 2. Maturity indexing (Streif index) of apples on 4 October 2018 ( $n=10$ per treatment).

\begin{tabular}{ccccc}
\hline Treatment & \multicolumn{2}{c}{ Streif Maturity Index } & \multicolumn{2}{c}{ Streif Expectation } \\
\hline $\begin{array}{c}\text { Control 1 + } \\
\text { 2/grass }\end{array}$ & 0.32 & SD & 0.14 & Max \\
\hline Aluminium foil & 0.3 & 0.18 & 0.14 & 0.25 \\
\hline $\begin{array}{c}\text { Lumilys every } \\
\text { row }\end{array}$ & 0.3 & 0.19 & 0.14 & 0.25 \\
\hline $\begin{array}{c}\text { Lumilys } \\
\text { relocation P. 1 }\end{array}$ & 0.26 & 0.05 & 0.14 & 0.25 \\
\hline $\begin{array}{c}\text { Lumilys } \\
\text { relocation P. 2 }\end{array}$ & 0.26 & 0.08 & 0.14 & 0.25 \\
\hline $\begin{array}{c}\text { Lumilys } \\
\text { alternating rows }\end{array}$ & 0.39 & 0.07 & 0.14 & 0.25 \\
\hline $\begin{array}{c}\text { Stimplex } \\
\text { biostimulant }\end{array}$ & 0.2 & 0.22 & 0.14 & 0.25 \\
\hline
\end{tabular}

In Table 2, grey colour background represents metal, blue plastic and green a chemical alternative.

\subsection{Economics}

The additional proceeds, as a result of the colour improvement, were calculated by taking the percentage change of the apples with more than $50 \%$ red colour as compared to the control. The price difference between fruits with $>50 \%$ red colour, which sell at an average of $0.45 € / \mathrm{kg}(€ 0.35-0.55)$, and those with less than $50 \%$ red colour, which sell at an average of $0.08 € / \mathrm{kg}$, was multiplied by yields of $30 \mathrm{t} / \mathrm{ha}, 40 \mathrm{t} / \mathrm{ha}$ and $50 \mathrm{t} / \mathrm{ha}$. The results show that the largest financial gain was from well-coloured fruit from trees with reflective mulch in every other alleyway (row), followed by aluminium foil (under the tree) and then 
Lumilys in every alleyway/row ("traditional" approach) and change P. 1. These results confirm that Lumilys in alternating alleyways/rows and aluminium foil represent possible alternatives to spreading reflective mulches like Lumilys ${ }^{R}$ in every row (Figure 1a).

The calculation is based on the cost for Lumilys ${ }^{\mathrm{R}}$ reflective mulches $(2700 \mathrm{~m} / \mathrm{ha})$, at $50 \mathrm{cent} / \mathrm{m}^{2}$ (plus $240 € /$ ha hooks), and the recycled aluminium foil, at $51 \mathrm{cent} / \mathrm{m}^{2}$ (plus $328 € /$ ha sandbags), which hardly differed. The biostimulant Stimplex ${ }^{\mathrm{R}}$ was more economical due to the lower cost of $151 € /$ ha for two product applications $(2 \times 4 \mathrm{~L} / \mathrm{ha})$ and a low workload. Annual costs were based on a 10-year lifespan for Lumilys and a single or double use of the (recycled) aluminium foil.

A financial gain as a difference between gross income and cost was seen in the reflective mulch in every other alleyway/row ("alternating"), aluminium foil (under the tree), Lumilys and change P. 1, as compared to control/grass. Based on a yield of $50 \mathrm{t} / \mathrm{ha}$, a financial gain was achieved with (i) Lumilys ${ }^{R}$ in every row $1091 € /$ ha), (ii) Lumilys ${ }^{R}$ in every other row ("alternating") $(2899 € /$ ha), and (iii) aluminium foil (1388 $€ /$ ha), while the triple re-location of the Lumilys ${ }^{\mathrm{R}}$ foil saves $50 \%$ in material costs but is not profitable due to the insufficient red colour of the apples for marketing as premium fruit (Table 3).

Table 3. Financial gain of employing the four alternatives for fruit colouration.

\begin{tabular}{|c|c|c|c|c|c|c|c|}
\hline \multirow{2}{*}{$\begin{array}{l}\text { Parameter } \\
\text { Yield: }\end{array}$} & \multicolumn{3}{|c|}{ Additional Revenue Per Hectare } & \multirow[t]{2}{*}{ Cost/ha } & \multicolumn{3}{|c|}{ Financial Gain } \\
\hline & 30 t/ha & $40 \mathrm{t} / \mathrm{ha}$ & $50 \mathrm{t} / \mathrm{ha}$ & & $30 \mathrm{t} / \mathrm{ha}$ & $40 \mathrm{t} / \mathrm{ha}$ & $50 \mathrm{t} / \mathrm{ha}$ \\
\hline Control & 0 & 0 & 0 & 0 & 0 & 0 & 0 \\
\hline $\begin{array}{l}\text { Aluminium } \\
\text { foil }\end{array}$ & $2171 € /$ ha & $2895 € /$ ha & $3619 € /$ ha & $2231 € /$ ha & $-60 € /$ ha & $664 € /$ ha & $1388 € /$ ha \\
\hline Lumilys & $1689 € /$ ha & $2253 € /$ ha & $2816 € /$ ha & $1725 € /$ ha & $-36 € /$ ha & $528 € /$ ha & $1091 € /$ ha \\
\hline $\begin{array}{c}\text { Relocation } \\
\text { P.1 }\end{array}$ & $1457 € /$ ha & $1943 € /$ ha & $2429 € /$ ha & $1733 € /$ ha & $-276 € /$ ha & $210 € /$ ha & $696 € /$ ha \\
\hline $\begin{array}{c}\text { Relocation } \\
\text { P.2 }\end{array}$ & $-118 € /$ ha & / & / & $1733 € /$ ha & / & / & / \\
\hline $\begin{array}{c}\text { Alternating } \\
\text { rows }\end{array}$ & $2335 € /$ ha & $3114 € /$ ha & $3892 € /$ ha & $993 € /$ ha & $1342 € /$ ha & $2121 € /$ ha & $2899 € /$ ha \\
\hline Stimplex & $-534 € /$ ha & / & / & $139 € /$ ha & I & / & / \\
\hline
\end{tabular}

/ no colour improvement relative to the untreated control, red background indicates financial losses, green financial gains.

\subsection{Sustainable Apple Colouration-Economic and Ecological Aspects}

Current criticism in the public and media targets the excessive use of plastic in the fruit supply chain $[4,17-20]$. The present study has shown that the use of plastics for fruit colouration could be decreased in three ways. Both the plastic mulch (Lumilys) in every other row and aluminium produced apple fruit with sufficient fruit colouration for economic marketing as premium fruit in class I and saved $50 \%$ or $100 \%$, respectively, of plastic input in the orchard. The traditional use of plastic mulch in the alleyway in every row [21,22] is associated with $2700 \mathrm{~m}$ rolls $\times 2.6 \mathrm{~m}$ width $\times 0.1 \mathrm{~kg} / \mathrm{m}^{2} \Rightarrow 700 \mathrm{~kg}$ polypropylene/ha. Using the emission factor of 2.2-3.2 $\mathrm{kg} \mathrm{CO}_{2} \mathrm{eq} / \mathrm{kg} \mathrm{PP}$ (PlasticsEurope, Brussels, Belgium, 2005) [23], this is equivalent to GHGs of 1.5-2.2 t $\mathrm{CO}_{2 \mathrm{eq}} /$ ha for full orchard coverage $(100 \%)$. A reduction in the use of plastic mulch in every other row (or translocation) would hence save $0.75-1.1 \mathrm{t} \mathrm{CO}_{2} \mathrm{eq} / \mathrm{ha}$ in the material alone, with a multiple use, for ca. 10 years, of $75-110 \mathrm{~kg} \mathrm{CO}$ eq/ha/year.

For one hectare, $108 \mathrm{~kg}$ of aluminium foil is required to substitute the plastic mulch in every row. Aluminium production requires a high energy input of $13-16 \mathrm{kWh} / \mathrm{kg}$ aluminium (Hydro Inc., Chicago, IL, USA, 2016) [24]. Hence, it often takes place where energy is cheaply available, adding long-distance transport to the final validation. We used aluminium for the first time, since recycled material became available, which contains $80 \%$ recyclat and requires only $20 \%$ of new aluminium for its production. Based on the German electricity grid emission factor of $0.6 \mathrm{~kg} \mathrm{CO}_{2} \mathrm{eq} / \mathrm{kWh}$, the GHG emissions associated with the production of primary aluminium are equivalent to $7.8-9.6 \mathrm{~kg} \mathrm{CO}_{2}$ eq $/ \mathrm{kg}$ aluminium. Per acreage, with a need for $108 \mathrm{~kg}$ aluminium per hectare, this amounts 
to $821-1037 \mathrm{~kg} \mathrm{CO}_{2 \mathrm{eq}} / \mathrm{ha}$. Since the employed aluminium foil was made of $80 \%$ recycled aluminium with ca. 10\% GHG of the primary aluminium (Hydro.com 2016), this results in $223-290 \mathrm{~kg} \mathrm{CO}$ eq/ha. However, using aluminium foil made from $100 \%$ recycled aluminium would reduce the value to $82-104 \mathrm{~kg} \mathrm{CO}_{2 \mathrm{eq}} / \mathrm{ha}$ (Table 4). Even using the aluminium foil twice could significantly reduce the $\mathrm{CO}_{2}$ load to between 112 and $145 \mathrm{~kg}$ $\mathrm{CO}_{2} \mathrm{eq} / \mathrm{ha}$. A combination of $100 \%$ recycled aluminium foil with a 2-year use would reduce the $\mathrm{CO}_{2}$ burden to $41-52 \mathrm{~kg} \mathrm{CO}$ eq/ha. The decisive factor is that the use of the $100 \%$ recycled aluminium foil is associated with less $\mathrm{CO}_{2}$ emissions, which makes its use more sustainable.

Table 4. Greenhouse gas (GHG) emissions associated with different scenarios of employing mulches for fruit colouration.

\begin{tabular}{|c|c|c|c|}
\hline Material & Material Input/ha & $\begin{array}{l}\text { Lifespan } \\
\text { (years) }\end{array}$ & $\begin{array}{c}\text { GHG Emissions } \\
\text { (kg CO } \mathrm{CO}_{2} / \mathrm{ha} \& \mathrm{c} \\
\text { year) }\end{array}$ \\
\hline $\begin{array}{c}\text { Lumilys } \\
\text { (polypropylene) } \\
\text { every row }\end{array}$ & $700 \mathrm{~kg} \mathrm{PP} / \mathrm{ha}$ & 10 & $150-220$ \\
\hline $\begin{array}{l}\text { Lumilys change and } \\
\text { alternating rows }\end{array}$ & $350 \mathrm{~kg}$ PP/ha & 10 & $75-110$ \\
\hline $\begin{array}{l}\text { Aluminium foil } 80 \% \\
\text { recycled aluminium }\end{array}$ & $108 \mathrm{~kg}$ alu $/ \mathrm{ha}$ & 1 & $223-290$ * \\
\hline $\begin{array}{l}\text { Aluminium foil } 80 \% \\
\text { recycled aluminium }\end{array}$ & $108 \mathrm{~kg}$ alu $/ \mathrm{ha}$ & 2 & $112-145$ * \\
\hline $\begin{array}{l}\text { Aluminium foil 100\% } \\
\text { recycled aluminium }\end{array}$ & $108 \mathrm{~kg}$ alu $/ \mathrm{ha}$ & 1 & $82-104$ * \\
\hline $\begin{array}{l}\text { Aluminium foil } 100 \% \\
\text { recycled aluminium }\end{array}$ & $108 \mathrm{~kg}$ alu $/ \mathrm{ha}$ & 2 & $41-52$ * \\
\hline
\end{tabular}

Both results of the colour measurements in the field (Figure 3) and machine grading (Figure 5) show the large potential for colour improvement in situations with colouration problems on the East side (morning sun, weak and short) and in the lower part (below $1 \mathrm{~m}$ ) of the tree canopy (Figure 3).

This environmental benefit is largely caused by the fact that the aluminium foil was not laid out over the entire alleyway, due to its regular reflection property [25]. At present, the single use of the aluminium foil in an orchard protected by a hail net may be extended to two years, looking at the clean stage of the material at the end of its use in the orchard under our conditions (Figure 1a). The aluminium foil employed consisted of $80 \%$ recycled aluminium and may be used for another year, depending on its contamination. Meanwhile, there are also aluminium foils made of $100 \%$ recycled aluminium, which is sustainable. The possibility of recycling the aluminium foil used depends on the degree of contamination, and it may even be recycled again.

Despite its origin from fossil fuel, the use of reflective polypropylene (PP) mulches such as Lumilys ${ }^{\mathrm{TM}}$ is sustainable, when used repeatedly (7-years warranty-estimated 10-year lifespan) and properly disposed of. At the waste collection points, the plastic material is washed, shredded and then melted - the PP pellets/granules are the source of recycled plastics such as boxes or flower pots [17].

\section{Conclusions}

The sustainability aspect is judged here on the basis of a sufficient red colour of the apples, which determines their sales price and orchard (bio-)economy. Short-lived biodegradable plastic mulches [4] are not suitable for this purpose, if fossil-fuel based. The use of aluminium foil made of $80-100 \%$ recycled aluminium is associated with considerably lower $\mathrm{CO}_{2}$ emissions than new aluminium, with its high energy demand. Both the recycled aluminium foil with single (or duplicate) use, and the Lumilys plastic mulch, 
a material with a long lifespan, used twice a year over several years and/or in every other row, results in ecologically and economically sound horticulture and could be further improved by recycling the fairly clean white single pure plastic polypropylene.

Author Contributions: Conceptualization, M.M.B.; methodology, A.K.; investigation, P.H.; resources, A.K.; writing—draft preparation, P.H.; writing—review and editing, M.M.B.; supervision, M.M.B. All authors have read and agreed to the published version of the manuscript.

Funding: This research received no external funding.

Acknowledgments: We thank Simon John von Freyend for revising the English and HJ Wiesel for the professional cultivation of the experimental fruit trees at Campus Klein-Altendorf (CKA) and MDPI for the invite to this article and for waiving the APC.

Conflicts of Interest: The authors declare no conflict of interest.

\section{References}

1. Blanke, M.M. Reducing ethylene levels along the food supply chain-a potential key to reducing waste? Invited "Perspective". J. Sci. Food Agric. 2014, 94, 2357-2361. [CrossRef] [PubMed]

2. Gierling, F.; Blanke, M.M. Carbon reduction strategies for regionally grown and locally consumed white and red wine. J. Environ. Manag. 2021, 278. [CrossRef] [PubMed]

3. Bosančić, B.; Mićić, N.; Blanke, M.M.; Pecina, M. Effects of netting on fruit quality-a main effects meta principal components analysis (PCA) using apple as a model. Plant Growth Regul. 2018, 86, 455-465. [CrossRef]

4. Yang, Y.; Puwang, L.; Jing, J.; Minghze, L.; Yonghzen, L.; Chuang, Z.; Chao, W.; Zuyu, H.; Liu, Y.; Song, S. Renewable sourced biodegradable mulches and their environment impact. Sci. Hortic. 2020, 268, 109375. [CrossRef]

5. Solomakhin, A.A.; Blanke, M.M. Overcoming adverse effects of hailnets on fruit quality and microclimate in an apple orchard. J. Sci. Food Agric. 2007, 87, 2625-2637. [CrossRef]

6. Blanke, M.M.; Kunz, A. Effect of climate change on pome fruit phenology at Klein-Altendorf-based on 50 years of meteorological and phenological records [Einfluß rezenter Klimaveränderungen auf die Phänologie bei Kernobst am Standort Klein-Altendorf]. Erwerbs-Obstbau 2009, 51, 101-113. [CrossRef]

7. Hamadziripi, E.; Muller, M.; Theron, K.J.; Steyn, W.J. Consumer preference for apple eating quality and taste in relation to canopy position. Proc. ISHS Stellenbosch congress Dec 2012 (K. Theron, ed). Acta Hort. 2014, 1058, 254-260.

8. Blanke, M.M. Alternatives to reflective mulch cloth $\left(\right.$ Extenday $^{\mathrm{TM}}$ ) for apple fruit colouration under hail nets? Sci. Hort. 2008, 116, 223-226. [CrossRef]

9. Weber, S.; Damerow, L.; Kunz, A.; Blanke, M.M. Anthocyanin synthesis and light utilization can be enhanced by reflective mulch-visualisation of light penetration into a tree canopy. J. Plant Physiol. 2019, 233, 52-57. [CrossRef]

10. Smrke, T.; Persic, M.; Verberic, R.; Sircelj, H.; Jakopic, J. Influence of reflective foil on persimmon (Diospyros kaki Thumb.) fruit peel colour and selected bioactive compounds. Sci. Rep. 2019, 9, 19069. [CrossRef]

11. FAOSTAT. Crops, Data. Available online: http:/ / www.fao.org/faostat/en/\#data/QC/visualize (accessed on 20 June 2020).

12. Jackson, J.E.; Palmer, J.W. Interception of light by model hedgerow orchards in relation to latitude, time of year and hedgerow configuration and orientation. J. Appl. Ecol. 1972, 341-357. [CrossRef]

13. Meinhold, T.; Damerow, L.; Blanke, M.M. Reflective materials under hailnet improve orchard light utilisation, fruit quality and particularly fruit colouration. Sci. Hort. 2011, 127, 447-451. [CrossRef]

14. Beaulieu Technical Textiles, 2018. Lumilys-Smart reflective ground cover. Available online: http://www.lumilys.com (accessed on 22 September 2020).

15. Blanke, M.M. Possibilities of improving apple fruit colouration [Möglichkeiten zur Verbesserung der Rotfärbung bei Äpfeln—A review]. Erwerbs-Obstbau 2015, 57, 47-62. [CrossRef]

16. Blanke, M.M.; Kunz, A. Alternatives to phosphonates for fruit colouration. Sci. Hort. 2016, 198, 434-437. [CrossRef]

17. Schuhknecht, H.; Damerow, L.; Kunz, A.; Blanke, M.M. Colour development of apple with reflective mulches and biostimulants. Acta Hort. 2018, 1228, 433-439. [CrossRef]

18. Blanke, M.M. Biostimulants in horticulture-a review Biostimulantien im Gartenbau-eine Branche (er-)findet sich-A review. Erwerbs-Obstbau 2016, 58, 82-87. [CrossRef]

19. Blanke, M.M. Circular economy of (micro-)plastic in horticulture. GKL-Tagung zur Bestandesaufnahme von Mikro- und Makroplastik im Obst- und Gartenbau. Erwerbs-Obstbau 2020. [CrossRef]

20. Blanke, M.M. Bessere Farbe und Fruchtqualität durch Reflexionsfolien. Besseres Obst. 2018, 65, $19-23$.

21. Andris, H.L.; Crisoto, C.H. Reflective materials enhance 'Fuji' apple color. Calif. Agric. 1996, 50, 27-30. [CrossRef]

22. Prive, J.P.; Russell, L.; Leblanc, A. Use of Extenday ground cover on production of 'Gala' apples (Malus domestica) in New Brunswick, Canada. N. Z. J. Crop Hortic. Sci. 2008, 36, 221-230. [CrossRef]

23. PlasticsEurope, 2005. Free download from homepage or access via Simapro or GaBi Plastics Europe was earlier called APME. Available online: www.plasticseurope.org/en/resources/eco-profiles (accessed on 30 September 2020). 
24. Hydro.com. 2016. Available online: https://www.hydro.com/de/hydro-in-deutschland/uber-aluminium/aluminiumlebenszyklus/recycling/ (accessed on 1 October 2020).

25. Meinhold, T.; Damerow, L.; Richters, J.P.; Blanke, M.M. Optical properties of reflective ground covers with potential for enhancing fruit colouration. Biosyst. Eng. 2010, 107, 155-160. [CrossRef] 